\title{
'This is an opportunity for librarians to reinvent themselves, but it is about moving out of their areas.' ' - new roles for library leaders?
}

\section{Roisin Gwyer}

To cite this article: Roisin Gwyer (2018): 'This is an opportunity for librarians to reinvent themselves, but it is about moving out of their areas.' ' - new roles for library leaders?, New Review of Academic Librarianship, DOI: 10.1080/13614533.2018.1473258

To link to this article: https://doi.org/10.1080/13614533.2018.1473258

Accepted author version posted online: 08

May 2018.

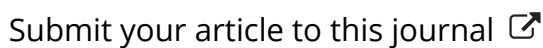

Q View related articles ¿

View Crossmark data $₫$ 
Publisher: Routledge

Journal: New Review of Academic Librarianship

DOI: https://doi.org/10.1080/13614533.2018.1473258

'This is an opportunity for librarians to reinvent themselves, but it is about moving out of their areas.' ' - new roles for library leaders?
Author
Roisin Gwyer
University Librarian
University of Portsmouth

University Library

Cambridge Road

Portsmouth

POI 2ST

roisin.gwyer@port.ac.uk

\section{Abstract}

This paper shares research based on interviews with 12 UK university senior managers commissioned by SCONUL and carried out by external consultants which found that libraries can have a positive impact on student satisfaction and experience and are a source of institutional information about the student body. Libraries are seen very 
much as supporting learning and teaching; centrality to research was less apparent. They are rarely seen as problematic except in terms of future resource levels, but there is awareness that rapid change will continue to affect libraries; library leaders will need to provide innovative solutions to this and other challenges. The need for strategic alignment is key. These findings are seen within the context of a survey of senior librarians carried out by SCONUL showing a trend towards greater centralisation of services. The position of the senior librarian is now lower ciown the reporting structure than in the past.

\section{Introduction}

This article will discuss work recently completed by a Task arid Finish Group of SCONUL (Society of College, National and Universliv Libraries) in the UK. The Leadership Task and Finish Group was estaiblished in 2016 to carry out an 18-month project called 'Leading libraries', de (eloping in tiatives to enhance the collective leadership capacity of the sector.

SCONUL represents university libraries in the UK and Ireland, as well as national libraries and many of ihe U.'s colleges of higher education, aiming to promote awareness of the role of ucademic libraries in supporting research excellence and student gchievernent and employability. Its membership consists of institutions and the instilitional representatives are primarily the heads of library services in these institutions (i.e. it is not an individual member organisation).

The Task and Finish Group ('the Group') arose from the SCONUL Strategy 2016-19. The Strategy itself was informed by a survey of members which identified 'the most significant leadership and management issues facing institutions and the library community in general over the coming three years'. Three closely connected 
themes were identified - leadership, vision for library services and advocacy and proving value. Specifically there was an identified need for a programme of leadership capacity building across the sector. The Group was set the task of 'working to ensure directors have the skills and attributes they require to deliver and to support the modern academic library', echoing similar concerns elsewhere.Binin (2015) surveyed US senior library leaders in large and medium-sized academic libraries to find their top five major challenges in a digital age. The 14 returned surveys indicated that the top challenges were: demonstrating libray values to the university, operating under fiscal uncertainty, fitting new servifes within old buildings, balancing print and digital materials and keeping library'staff trained and current. Binh saw the top five leadership skills as vision, integrity, management, collaboration and communication and suggested a number of ways to develop these skills including, most pertinently for this paper, a call to 'get out of your comfort zone' and 'seek leadership roles, especially on caripus' (p. 308). A recent paper from Hong Kong (Gabrielle, 2017) reviews ssme of the library leadership literature from the viewpoint of emerging leaslers, tearn leaders and headship and states that the development of legdership capabilities has been of interest to librarians 'for decades' withovit produsing 'a cohesive body or any framework on understanding leadership ...'10.153). Librarians primarily see leadership as a process of influence. Harris-Keith (20,6) on the other hand believes that research has established a list of iecalershiip skills and is more concerned with how these skills are developed, finding ihat some (fundraising, safety issues, legal issues, compliance issues and facilities planning) only seem to be acquired at Assistant Director and Director level.

The Group successfully delivered a number of outputs - such as a mentoring scheme - which can all be found on the SCONUL website (www.sconul.ac.uk); this article is mainly concerned with describing the findings of a survey of SCONUL members plus 
interviews with senior institutional leaders across the UK Higher Education (HE) sector which looked at the scope of activity of library leaders, the way they are viewed by the senior leaders within their institutions and sought to get some advice on how library leaders could move into wider institutional leadership roles. It hopes to disseminate the findings to a wider audience and frame it within the wider literatyrs on the subject in the hope that this will resonate beyond the UK.

The small literature on the topic of perceptions of library leaders by the senici management of the university is considered to set the context. The two pieces of work described are considered under the headings of: changing roles and reporting lines; the need to develop new leadership models and the rise: of multi-professional teams. Finally these themes are drawn together and possible ways forward discussed.

\section{The literature}

There is not a large body of literaiure concerned with the view of the library or librarian from above: "strdies ot the views of provosts or other senior administrators regarding academic libraries are surprisingly few and far between' (Robertson, 2005, p.492). Most of tine iterature identified is from the US (and much in a single journal) and is mainiy obou' the role of the library rather than the library director. What there is goes Bafk olong way, however. There are different terms used in the literature to dEscribe those who lead libraries, this article mainly uses the term 'library director' to deingte this. Readers should be aware that US articles often refer to senior managers within universities as 'the administration'.

The classic article was written by Robert Munn, an academic library director turned senior administrator, in 1968. Munn saw library directors as having little 
understanding of how senior academic administrators (those who make major funding decisions) saw the library. His experience as a senior administrator showed him that the library is little considered for a number of reasons: it is "an academic sleeping dog ... unlikely to be the cause of either a crisis or a coup' (p.52) and its share of the institutional budget is small and reasonably consistent. When it is considered it is seen as a 'bottomless [money] pit' (p.52) as there are no theoretical limits to the library's needs, rather it is 'tradition, what other institutions are dring. academic politics, and the personal predilections of the officials involved [wich] tends to determine budget support' (p.53).

Hardesty (1991) revisited this view a generation later inferviewing 39 chief academic officers from selective liberal arts colleges in the U'S. These are typically small colleges with an undergraduate focus, good levels of funding and strong libraries. He found that, contrary to Munn's experiense, there was a good understanding of the role of the library in support of the irsstitutional mission, indeed at a few colleges the deans interviewed saw c. vider role for the library than was being delivered and a few observed 'conservatisn grinong head librarians' (p. 225) who were hesitant to adopt new technologies and formats and to take on new responsibilities. There was great symbolis raive attached to libraries which were seen as a Good Thing. Hardesty identified' an element of 'benign neglect' (p.225) mainly because library directors vere seen as good managers who brought no problems to their deans, although there was recognition from some that library directors could become isolated because of this. Hardesty felt that deans, whilst having 'considerable respect for the administrative skills of their library directors', apparently did not 'consider these skills applicable to larger college concerns' (p. 227), he recommends library directors take 'an active and informed interest in larger college 
problems and general educational issues' and 'understand how to work aggressively within the framework of academia' (p.228).

Deemer (2007), following in the footsteps of Munn as a library director stepping up into a senior administration role, agrees with Munn that the library 'creating neither work or problems' (p.26) was not in his thoughts much. However his experience gave him a wider view of how the library could 'enhance the campus's eavcationci! and social missions' (p.26).

Themes picked up in these three classic articles are: the position of the library in the organisational hierarchy; the lack of recognition of the skills of likrary directors as transferable tomore senior posts and the possibly isolating effects that being seen as a well-managed unit can have on a service.

The year 1971-2 saw an unprecedented number of library directors from large US universities leaving post before the usu ai retirement age. McAnally and Downs (1973) interviewed 22 library directiors who had recently left their posts to identify what they saw as the pressures of library leadership. A number of these are familiar, e.g. growth in student numbers ) and reduced budgets. Interestingly added layers of hierarchy between librarians and administrators with power so that the library director ho longer bas direct access to the president is mentioned. One interviewee comimented that "unfortunately the presidents rarely have utilized existing administrators, such as directors of libraries, who have broad overview of the University, to help with the growing burden of general administrative affairs' (p.105).

Grimes (1998) looked at the 'centrality' of the library and showed the importance of understanding the wider academic community. She found a lack of understanding of the role information literacy as delivered by the library could play - from 
academics, students and administrators. She also found that library directors did not participate at the highest levels of the university's administration.

McElrath (2002) examined perceptions of challenges reported by academic library directors (ALDs) and the chief academic officers (CAOs), to whom they report, in the south of the US. The study showed some close co-relation in challenges identified by both groups but also areas of difference. Respondents were able tc add areas of challenge to the list supplied by the researchers (which wivs derived from the literature). ALD's most frequently added challenge was cround staffing issues whilst the CAO's was the library's role (which was mentioned oy ALDs but in smaller numbers). The 'problem of integrating the library in the university's mission was mentioned by some respondents from both groups' (p. 314/5).

These earlier studies show how libraries are changing place within organisational structures, moving down the hierarchical ksvels as universities grow staff numbers in senior roles and add functions. There is scrne lack of understanding of what libraries can do in certain areas an, a feeling from some administrators that the library is isolated from the wider institution and a desire for library directors to place their services within the straiegic plan of the organisation. Some of the library directors interviewed sincw a lack of comfort with new expectations.

A studiy of nine Canadian provosts ('chief academic visionary' posts) from researchintensive universities (Robertson, 2015) explored how they perceive academic libraries in the context of their evolving institutions. All respondents saw the library as critical in supporting the research function although the majority see this in traditional terms of preserving and disseminating research. Student learning was also seen as a critical role for the library, particularly in providing a variety of learning spaces and as a 'platform' for the co-location of and collaboration with learning 
support (and other) services, although the library role in information literacy was not recognised across the board (and the term 'information literacy' never used). For the future there was consensus that librarians need to become more embedded and active partners in research, teaching and learning and building crossinstitutional digital collections.

More recently Murray and Ireland (2017) note and attempt to fill the gap intargescale studies into the perceptions of college or university provosts of library value and communication preferences. Their study of 209 provosts/chiet academic officers in the US concludes that the respondents "tend to riote that the biggest barrier for academic libraries to be involved with campus initict ves is that the campus overall doesn't recognise that potential $(\mathrm{p} 2 \pi)$

The Ithaka S+R Library Survey of 2016 (Wosif 2017/ found that US library directors feel a decreasing sense of support from their institutions: they 'feel increasingly less valued by, involved with, and cligined strciegically with their supervisors and other senior academic leadersh:ip' ip.4. Compared to the previous survey of 2013 fewer library directors feel that they are part of the senior academic leadership and that they share the samie vision for the library with their direct supervisor. This survey gauges the perce otions of library directors, and their perceptions of how their linemanagers woyid feel about certain issues - it does not ask the line-managers dire cilly. There was an alignment between feeling one has a well-developed vision and strategy and feeling part of the senior academic leadership of the institution. Roughly $60 \%$ of respondents believe that their institution's senior academic leadership considers the library to be an important contributor to student success, although only about $50 \%$ of respondents feel they themselves have clearly articulated what this contribution is. 
Harland, Stewart and Bruce (2017) used constructivist grounded theory research with 12 experienced library directors from the US and Australia to look at how to ensure the academic library's relevance to stakeholders. 'Participants stressed the importance of ensuring that the vision, goals and strategy of the library were aligned with those of the university' (p.400) - the lessons of the early articles have clearly been learnt - although the authors found some evidence that some US academic libraries are still not aligning their plans in this way. The library directors rored a culture of complacency which could disadvantage libraries 'there's an attitude that libraries and librarians always cope with whatever you throw acthem:' (p.403). Demonstrating value was seen as a major challenge, os was dealing with outdated perceptions and ignorance about the library.

A recently commissioned report, again for SCDNIJI Rinfield, Cox \& Rutter, 2017), picks up a number of these issues. The report is based on a literature review, interviews with 33 national and international key stakeholders and a survey of UK HE library staff which had 261 responses. The research found that the library is seen as 'a reliable but fundamen ing yeil-understood and unchanging part of campus' (p.42). There are increcisingiy blurred boundaries between the library and other parts of the university leading to a lack of clarity about what a library is, whilst at the same time many stakeholders still have traditional perceptions of 'library'. The need to clign close'y with the organisation is seen as key as is providing leadership in key areas within the institution. There was some feeling that the library profession is too inssiar - collaboration between librarians is good but liaison with other professional groups less so, although these are seen as crucial. In some cases collaboration becomes competition over jurisdiction of an area of work. Collaboration can also contribute to the erosion of the library's identity. Finally, there was evidence of a lack of innovative thinking and risk taking. 
These later studies show some senior administrators identifying a need for more collaboration and embedding of library services (both within the institution and externally) - whether that is learning, teaching or research or for shared space with other learning support services. Librarians still feel that their services are viewed in a rather traditional way although there is also a recognition that demonstrating their value to others within the institution is difficult.

The themes of the classic articles remain throughout the literature surveved, library directors are eternally concerned with discerning their role and function within the changing organisation and sector. This leads to a lot of soy'senrehing land some doom and gloom) but demonstrates active commitment to providing effective services. Some of this soul searching may come from the fact that librarians see themselves 'slipping' in the organisational hierarchy 't'ardesty, 1991; McAnally \& Downs, 1973; Grimes, 1998; Woolf, 2017!

Librarians are seen as good maricigers aria a 'safe pair of hands' able to weather whatever their institutions throw at them (Hardesty, 1991; Harland et al., 2017), but not necessarily as inn oy ative or willing to take risks (Hardesty 1991; Pinfield et al., 2017). There is giack of recognition of the potential of the Library and a traditional (outdated) View of what libraries can do (Murray \& Ireland, 2017; Harland et al., 2017), meither is the potential of the library director always recognised (Hardesty 1991 : Mchrially \& Downs, 1973; Grimes, 1998). However, there is a recognition that libraries provide well used spaces indeed there are suggestions that the success of this space is shared with other services (Robertson, 2015).

Finally there is a recognition that libraries need to align strategically with the parent organisation (McElrath, 2002; Harland et al., 2017; Pinfield et al., 2017), but a lack of clarity from senior administrators about what a library is, or could be, in a digital age 
(Grimes, 1998; McElrath,2002; Pinfield et al., 2017 ).The work of the SCONUL Group described below aimed to get a view from UK senior staff about their library directors, which can be compared to the literature above. It also took a snapshot of collaborations with other services.

\section{Methodology}

Two pieces of work are described - The View from Above ('VfA') and a survey of library directors ('the Survey').

'Leading libraries: the view from above' (Baker \& Allden, 2017a) is a piece of commissioned work which sought to explore, through interviews, three themes:

- what strategies can library leaders empioy to 'lead in uncertain times', i.e. which approaches to leadersinip are needed in the context of continuous and rapid organisationgi, legislative and technological change?

- what are the views of lyiversity senior leaders about academic library leadership and culture?

- what potential is there for library leaders to rise to senior executive levels in the institution?

A group of 12 senior managers was identified by the consultants (David Baker, an academic library director who later became a senior administrator and eventually University principal, and Alison Allden a senior administrator who later became Chief Executive of the UK Higher Education Statistics Agency) and members of the project sub-Group working together. This number was dictated by time and funding available and sought to be representative across the UK university mission groups 
(these are groups of universities with similar ethos and ambitions), geography, institutional size and range of senior roles. A small number of those interviewed had previously been librarians. Invitations were sent and one substitute made after one person declined. The interviewees included: five vice-chancellors (the vicechancellor is the top post in a UK university), two deputy vice-chancellors, two registrars, one pro vice-chancellor and two executive level directors of student services. Of these, three came from research-intensive universities, six from lorge post-92 universities (these are ex-polytechnics which gained universi y stottus and degree awarding powers in 1992 when the binary divide was cibolishiea) and three from small new universities including one specialist and one inclependent institution. The majority were based in England but there was one each from Scotland and Wales.

Library directors were made aware via a Sc:ONUL e-mail list that the interviews were taking place as a courtesy, but the names of the institutions involved were not shared. Interviewees were free to decide whether to talk to 'their' librarians but were not obliged to and hey were assured of anonymity. An interview checklist was compiled to ensure to pith consultants covered the same ground (this is included in the VfA documenit, as is the introductory letter). Questions were not piloted because of the shallenges in getting access to senior leaders. Telephone interviews of 45.60 minutes took place and detailed notes taken during the interviews. The ethical iramework and boundaries of the research were made clear at the boginning of each interview. Post interview notes were written up, anonymised and returned to the interviewees for comment and correction. The final versions, once agreed, were base-lined and have been securely lodged with the SCONUL office. Thanks should go to the interviewees who were generous with their time (indeed some interviews exceeded the 60 minutes suggested). 
Each of the consultants identified themes from their interview notes, these were then compared and a list of common themes identified, discussed and categorised. These were shared with the sub-group leading on this part of the project for comment, they also take account of the key topics and themes that emerged from a parallel literature review (Baker \& Allden, 2017b) carried out as part of the Leading Libraries work. The report itself aims to capture the words and tone of the interviews and extensive direct quotation is used (with permission but without direct attribution).

The second piece of work was a Leaders' Experience Survey of existing library directors which provided the basis for an experience and know edge sharing register available to directors in new roles or with new developments to lead on, e.g. a new library build. The Survey asked about responderts's job title, reporting structures, membership of strategic boards, scope of resporisibility and professional background as well as asking respondents to indicate areas of experience and interests which they would be willing to share with others in future. This gave a crosssectional snapshot of the section as at April 2017

The Survey was serit out via a SCONUL email list (LIS-SCONUL). SCONUL has a membership of 175 institutions which includes specialist colleges as well as national libraries arid also universities in the Republic of Ireland. A total of 88 responses were received rom university library directors which is a response rate of at least $50 \%$.

The Survey was mainly quantitative with tick box options for each category and a tree text box for 'Other'. Certain categories - membership of strategic boards, scope of responsibility and experience/interest which respondents were willing to share - allowed for more than one response per respondent. For the purposes of this 
article the position in structure and areas of responsibility totals are of most interest (see Table1).

\section{Findings}

The View from Above interviews identified some major themes incluaing.

- The library can have a positive impact on student satisfcction and experience

- The library is not a concern or a problern, Exsept in terms of future resource levels (space and funding) echoing Miurn (1968)

- Rapid and continuous change in the sector will affect library provision, this change will be driven by technology and quality assurance challenges and user expectohions

- There is a recognition that the library in some institutions is no longer the ceritralindependent unit it once was, and the library director is at least two tiers down in the senior staff structure echoing McAnally \& Downs (1973) and inne Ithaka Library Survey (Woolf, 2017)

There is a trend towards greater centralisation of services, although this has different forms and partnerships

- Library leaders need to provide innovative solutions to current and likely future challenges across the institution, including reduced budgets 
- There is a need for strategic alignment. The library was seen as key to learning and teaching but there was less evidence of centrality to research

- The 'embedded service culture' of libraries is a strength and an informed source of institutional information about the behaviour of the student body

The Survey found that only four library directors report directly to the Vice-Chancelian or Head of the institution. The majority of the others (58) report to posts alesignriated as Deputy Vice-Chancellor, Pro Vice-Chancellor, Registrar, Chief Inrormation Officer and Chief Operating Officer or equivalents. The remaining respendents report to posts designated Director of Learning and Teaching, Direcior of Lïurary \& Student Support or 'other Board member' or equivalents. Winilst ine survey did not ask for detail of exact institutional structures, so there is some degree of extrapolation here, it looks as if the place in the hierarchy of the Library Eirector is lower than it has been historically and reflects the literature eview.

In terms of membership of strategic decision making bodies only two library directors belong to the Vice Charicellor's Executive Board or equivalent. Membership of the senior managers group of the institution was 27, of Academic Board was 17, of Board of Governois or Cuuncil was 2, whilst 40 belonged to 'another' management board. A,acain this reflects the literature which shows that as management structures have grown the library becomes part of wider professional services structures.

The scope of responsibilities of library directors shows a changing picture from the past as can be seen in Table 1.

\section{Discussion}


The original SCONUL Strategy discussions identified the changing roles, position within the organisational hierarchy and structures of libraries within $\mathrm{HE}$, including the rise of multi-disciplinary teams often within differing models of convergence, as factors in the need to develop leadership models which differ from those of the past when libraries were more discrete services within their parent organisations. The literatyre review above echoes this with the earlier literature reflecting the days of large printbased collections with a high symbolic value which were central to the texching and research functions of the university. The library was a stand-alone uniti and the library director had a high status within a small senior managernent ieam.

\section{Changing roles and reporting lines}

The rise of larger management structures and new functions meant that the loneranger library director was no longer an appropriate model; strategic alignment of the library with the wider institution was diesirable. The decreased centrality of printbased collections as electronic resources became more widespread changed the role and functions of the library and an emphasis on space rather than physical collections has grown çuring this century. Bigger senior management teams have displaced those who would have had a place at the top table in the past, including the library sirector (as can be seen from the Survey results). The rise in posts such as Chief Sperating Officer, to which a number of UK library directors now report, rempved some library directors from the academic management structure and plac:ed them alongside infrastructural services and other 'professional services'. This has allowed different groupings and convergences to arise (and sometimes to be later dispersed) as more fluid structures become the norm in a time of more rapid and continuous change. 
Back in 1968 Munn described paying little notice to the library once he became a member of the senior administration. This is a theme throughout the literature and is reflected in the VfA. There is the idea, called 'benign neglect' by Hardesty (1991), that as libraries are generally well-managed and led they can be left to get on with things although there was recognition from some that library directors could become isolated because of this. The library directors interviewed by Harland Stewart and Bruce (2017) identified a culture of complacency which could disadvantage libraries 'there's an attitude that libraries and librarions alv'ays cope with whatever you throw at them' (p.403). This is again identified in VtA by senior managers one of whom remarked:

'The library is not a priority for my attention or the attenlion of the senior team, but for that reason it almost seems to beg further aitentiorr... it is well run ... there are many more pressing areas of the adminisiration that need attention'.

The rise of multi-professicnal iecims

The range of services currenily led by librarians, as reflected in the Survey results (see Table 1), is large. The recognised leadership and management skills of library directors is possilsy behind these library-led convergences. The VfA interviewees saw libraries as central to supporting students' learning and increasing student satisfaction with their university experience; and library directors as a source of iniormation and expertise about this:

'The librarian should be seen as a driver of understanding and change - able to provide insights that are valuable to the team, particularly about how students study and learn.' 
There was a recognition of the library's significant role in contributing to the student experience, this was indicated more strongly in the interviews than in the literature reviewed above and perhaps indicates the increasingly competitive environment for student recruitment and retention in the UK, as well as the central policy drive for quality.

It is notable in the Survey how many library directors have responsibility for studenit academic support - the fulfilment of the wish in the literature to see the library as a platform for the co-location and collaboration with academic support services (Robertson, 2015).

This movement of library directors into more general iecaiershiip roles leads senior managers to ask whether, in turn, you need a protessionuil librarian to run the library and some in VfA did just this:

'An important question for managers of licrarians would be "would it matter if the Director of Library Services wasn i there; what would/could be different?'

The need to develop new leadership models

The interviewess in VfA were vocal about the future for academic libraries and librarians in what they saw as a time of rapid and likely discontinuous change. In particulari technology (the move to more digital learning, teaching and research) and quality assurance were seen as disruptors, also the need to respond to student expectation, as one described it 'Amazon v. university infrastructure'. The skills set of the future library director was listed variously as change management, innovation, agility, driving and inventing new ways of working, being one step ahead, creativity and being a valued researcher in their own right: 
'Library leadership has to be about continuing to make yourself relevant to the institution and the long-term strategy; essentially it is about being completely on top of what the direction of the institution is and how best to support that'.

Many librarians will feel they already do this and some social media responses to reporting of this research (Reisz, 2017) indicated this. However another theme running through the literature is the lack of recognition of the skills of library directors as suitable for movement to the top table (McAnally \& Downs, 1973) allied with a feeling amongst library directors that the role of libraries is not understood beyond the traditional areas of accessibility and preservation (Grimies, 1998). Indeed a number of VfA interviewees advised library directors who want o be heard or to progress within their organisations to develop a brocder view beyond the library, to move out of their policy and managerial areds ana raise their profile and contribution:

'Never approach the role as a truditionai support role - see it as much broader.' Interviewees urged library directiors to extend their portfolios by volunteering to take on non-library chal!enges and think of university-wide solutions, this can involve an element of risk-terking:

'Libraries are inc' a problem. The things that are going to get you up the ladder are the problern areas'.

This e choes Hardesty (1991) who advised library directors to 'work aggressively V/vithin the framework of academia' (p.228).

VfA interviewees also advised recognising the skills one has and developing an understanding of the academic base of the institution as well as its managerial structures. 


\section{Conclusion - an opportunity for reinvention?}

The View from Above attempts, through interviews with senior staff in UK yniverslites to get some feeling for how they see their library directors. Although, the rumber of interviews was small and not subject to a rigorous research methoo ology ir does attempt to record the voices of a reasonable cross section of 'uk senior managers, the voices come through clearly in the quotations ingluded. Asking senior managers about their view of library leaders (rather than about the service as a whole) is both innovative and significant because there is ncthurig similar in the UK literature (although there are some US examples, . We car be an inward looking profession, Munn (1968) says 'academic librarians w'ory a lot' especially about 'the administration' (p.51). This work show's a professional group looking at how it is viewed, rather than how it sees itself, in order to make sense of leadership in a changing sector.

The Survey show's inat in the UK the library director role is now seen in some instityitions as pait of a professional services grouping rather than part of the asademic infrastructure and to report lower down the hierarchy than previously, which, is echoed in the literature discussed (Hardesty,1991; McAnally \& Downs, 1973; Grimes, 1998; Woolf, 2017).

An interesting UK trend is the move to larger groupings of services, as indicated in the Survey findings, many of these are currently led by librarians. There is a tension between the fact that librarians, seen as good managers and a 'safe pair of hands' 
are leading multi-professional groups, and the feeling expressed by a number of VfA interviewees that something else was needed in order to move up the institutional ladder, mainly leadership of 'problem' areas. The literature shows that library leaders are not seen as innovative or willing to take risks ((Hardesty 1991; Pinfield et al, 2017); it is probably easier to demonstrate these qualities when dealing with 'problem' areas.

Another tension, and a possible area for future research is what happens when the current (ex-library) leaders move on - will the next head of the multi-professional service come from the library or will there be a deficit of leadership skills because of being one in a larger grouping? Where do staff within larger structures develop leadership skills (will Harris-Keith's list of skills only develoned, at top level be longer in future)? A strong theme from the VfA intervie ws was thiat libraries are seen as having insight to the student voice and experience, this is something that library leaders can develop within the organisation. Being part of a multi-professional team can enhance this understanding.

The literature shows a lack of res ognition of the potential of the Library and an outdated view of vinaî libraries can do (Murray \& Ireland, 2017; Harland et al., 2017), the V/A interviews demonstrate a good understanding of how libraries support the studernt experience and learning and teaching but less overt understanding abcut the role of libraries in research support, outside of the traditional access and preservation roles, this is something library directors may wish to reflect upon.

The literature shows a lack of clarity from senior administrators about what a library is, or could be, in a digital age (Grimes, 1998; McElrath,2002; Pinfield, et al., 2017). A question for library directors to consider is what are the unique values and services which libraries bring to universities, how are these strategically aligned and 
effectively conveyed to senior managers? Binh's top five leadership skills of vision, integrity, management, collaboration and communication are valid and the call to develop these by 'getting out of your comfort zone' and 'seek leadership roles, especially on campus' $(2015$, p. 308) echoes the voice of many of the senior staff interviewed as illustrated by the title of this article.

With thanks to Alison Baud, Alison Allden, David Ford and David Baker for their helpfuli comments.

\section{References}

Baker, D. \& Allden, A. (2017a). Leading libraries: the viev from above. London :

SCONUL. Retrieved from: https://www.sconul.uc.uk/roublication/the-view-fromabove Accessed 27 Nov 2017.

Baker, D. \& Allden, A. (2017b). Leading libraries: leading in uncertain times: a literature review. London : SC ONUI. Retrieved from:

https://www.sconul.a. uk/pubuilcation/ leading-in-uncertain-times-a-literature-review Accessed 27 Nov $201 \%$

Binh P. Le. (2015). Academic library leadership in the digital age. Library Management, 36(4/5), 300-314

Deerner, K. (2007). A view from above, looking back, moving forward : a librarian's experience working as an interim assistant dean. College \& Research Libraries News, $68(1), 26-27$.

Gabrielle, Ka Wai Wong. (2017). Leadership and leadership development in academic libraries: a review. Library Management, 38(2/3), 153-166 
Grimes, D.J. (1998). Academic library centrality: user success through service, access, and tradition. Chicago:ACRL (ACRL Publications in Librarianship No. 50) Hardesty, L. (1991). The bottomless pit revisited. College \& Research Libraries, $52(3), 219-230$.

Harland, F., Stewart, G., \& Bruce, C. (2017). Ensuring the academic library's relevance to stakeholders: the role of the Library Director. The Journal of A.Caciemi:c Librarianship, 43(5), 397-408.

Harris-Keith, C.S. (2016). What academic library leadership lac:ks: leaclership skills directors are least likely to develop, and which positions offer development opportunity. Journal of Academic Librarianship, 42(11) 313-318

McAnally,A.M., \& Downs, R.B. (1973). The changirg role of directors of university libraries. College \& Research Libraries, 34(2), 103-125.

McElrath, E. ( 2002). Challenges that acaciemic library directors are experiencing as perceived by them and their surpervisors. College \& Research Libraries, 63(4),304-321. Munn, R.F. (1968). The bottomiess pit, or the academic library as viewed from the administration, buil ding. College \& Research Libraries, 29(1),51-54.

Murray. A. \& Ireland, A. (2017). Provosts' perceptions of academic library value \& preierences for communication: a national study. College \& Research Libraries, Retrieved from: https://crl.acrl.org/index.php/crl/article/view/16693/18169. Accessed 22 Mar 2018

Pinfield, S., Cox, A.M. \& Rutter, S. (2017). Mapping the future of academic libraries: a report for SCONUL. London: SCONUL. Retrieved from: 
https://sconul.ac.uk/sites/default/files/documents/SCONUL\%20Report\%20Mapping\% 20the\%20Future\%20of\%20Academic\%20Libraries.pdf. Accessed 04 Jan 2018.

Reisz, M. ( 2017, Nov 27). Librarians urged to shrug off stereotypes to scale ladder. Times Higher Education Supplement, p16.

Robertson,M. (2015). Perceptions of Canadian provosts on the institutional rote of academic libraries. College and Research Libraries, 76(4),490-511.

SCONUL Strategy 2016-19: Collaborating for change. London: SCO.NUL. Retrieved from: https://www.sconul.ac.uk/page/sconuls-strategy. Accessed 28 Nov 2017.

Wolff, C. (2017). Ithaka S+R Library Survey 2016. Ithak a Retrieved from:

http://www.sr.ithaka.org/publications/us-library-surve.y-?01\%/. Accessed 20 Nov 2017.

Table 1 - Scope of responsioilities of liorary directors $(n=88)$

\begin{tabular}{|l|c|}
\hline Area of responsibiliy & $\begin{array}{c}\text { No. of } \\
\text { Library } \\
\text { Directors }\end{array}$ \\
\hline Archives cinc. speccial collections & 65 \\
\hline Institutional research repository & 55 \\
\hline Rese drch support (e.g. publications, data management, open access) & 53 \\
\hline 'Other' & 38 \\
\hline VLE or e-learning or online courseware & 22 \\
\hline Student IT support & 18 \\
\hline
\end{tabular}




\begin{tabular}{|l|c|}
\hline Arts or community activities & 11 \\
\hline Learning and teaching development & 8 \\
\hline University press & 7 \\
\hline Learning/teaching space management (university-wide) & \\
\hline Careers/employability & 2 \\
\hline IT & 2 \\
\hline Information/knowledge management (university-wide) & 1 \\
\hline Student services
\end{tabular}

